\title{
Research on Ethical Problems of Chinese Food Firms and Implications for Ethical Education Based on Strategic CSR
}

\author{
Zhu Wenzhong \\ School of Business, Guangdong University of Foreign Studies \\ Guangzhou, China \\ Zhang Yanfang \\ School of Business, Guangdong University of Foreign Studies \\ Guangzhou, China
}

\begin{abstract}
Strategic CSR (corporate social responsibility) can be defined as a firm's management philosophy or practice of CSR that good deeds it does will bring profits and benefits to it in the long run. Such a philosophy or practice mainly stems from the motivation of economic benefits to be brought by social programs, which may have some potential ethical problems such as such activities may include some cheatings or hypocrisy which may harm customers and businesses themselves. The paper makes an in-depth research on the ethical problems of Chinese food firms based on strategic CSR, and the underlying reasons for firms involving in ethical scandals, and on this basis puts forward some countermeasures in order to prevent the occurrence of similar problems in the future.
\end{abstract}

Key words: strategic CSR; problems; reasons; countermeasure

\section{INTRODUCTION}

China is now facing a very serious CSR problem in its food industry. A lot of food scandals have been exposed by the media such as Sanlu Tainted Milk, McDnolds and KYC overdue meet, etc. Food consumers are all worried about whether what they eat every day is safe or not. They have gradually lost their confidence about the security of Chinese food, and even world-famous foreign-brand fast-food in Chinese market.

Corporate social responsibility is defined as the corporate management philosophy and practice that highlight both social and economic effects (Boone and Kurtz, 2002). It means that firms should undertake ethical and legal obligations in addition to creating profits to investors, in order to balance the interests of stakeholders, such as consumers, employees, the community, and the government, etc. Strategic CSR refers to a firm's management philosophy or practice of CSR that good deeds it does will bring profits and benefits to it in the long run, which means that the firm is acting in a socially responsible way such as donating money to social programs or charitable causes, expecting to have some economic returns from these good deeds. Strategic CSR is the very type of CSR most firms are taking in the practice because the act of a firm's social contribution is not only good for the society but also good for the investor's long-term profitability and development.

Real facts in the current China indicate that quite a lot of Chinese food enterprises including foreign-invested companies have not ethically followed their management philosophy of balancing the interests of consumers and investors in order to maintain the long-term sustainable development of the industry. It is thus important for researchers to conduct 
specific researches on the potential ethical problems of Chinese food enterprises based on the theory of strategic CSR.

This paper will make an in-depth research on the potential ethical problems of Chinese food firms based on the theory of strategic CSR, analyze the underlying reasons for firms involving in ethical scandals, and on this basis, put forward some countermeasures in order to prevent the occurrence of similar problems in the future.

\section{Status quo of CSR studies}

\section{LITERATURE REVIEW}

It is generally accepted that the concept of corporate social responsibility was first put forward by Oliver Sheldon in 1923. Ever since then, as a result of consumerism, human right movement and environmental friendly campaign, its influence has been increased step by step. Different schools of CSR theory have emerged at different eras. Friedman (1953,1973) in The Methodology of Positive Economics, Essays on Positive Economics puts forward his theory of CSR which is known as the theory of shareholders. He argues that the only social responsibility of a commercial business is to make profits to its investors or shareholders as a kind of fiduciary responsibility. He even argues that any business activities other than making money for investors will be considered to be unethical, because they have damaged the interests of investors. Carroll $(1991,1999)$ argues that there is a four-level pyramid of corporate social responsibility toward the moral management of organizational stakeholders, which include economic responsibility, legal responsibility, ethical responsibility, and altruistic responsibility, which means that economic responsibility is only one fundamental social responsibility concerning the survival of a firm, and in addition, it should also take the legally required social responsibility, the ethical suggested social responsibility, as well as the selectively advocated social responsibility. Vaughn (1999) argues that firms find long-term rewards to investors in doing good, so they are suggested to take social responsibilities in order to realize their sustainable development.

Freeman (2000), in his book "Strategic Management: An Approach", argues that firms' social responsibilities should be more than creating profits to investors to consider the interests of all shareholders in business operation. Thus, the theory of stakeholders comes into being, which has a great influence over the development of CSR. Based on the theory, a firm has both internal and external stakeholders which may have impacts on the development of a firm. These stakeholders and their interests in the firm are seen as Figure 2.1: 
Figure 2.1: Internal and external stakeholders and their interests

\begin{tabular}{|c|c|c|c|}
\hline $\begin{array}{l}\text { Name of } \\
\text { Stakeholder }\end{array}$ & $\begin{array}{l}\text { Type of } \\
\text { stakeholder }\end{array}$ & $\begin{array}{l}\text { Stakeholder's } \\
\text { Interests in the firm }\end{array}$ & $\begin{array}{l}\text { Impact of the firm's } \\
\text { unethical acts on } \\
\text { stakeholder }\end{array}$ \\
\hline Owners & Internal & $\begin{array}{l}\text { Investment profits, } \\
\text { dividends }\end{array}$ & $\begin{array}{l}\text { Loss of profits, no } \\
\text { dividend payment }\end{array}$ \\
\hline Employees & Internal & $\begin{array}{l}\text { Job security, fair pay, } \\
\text { fair opportunity }\end{array}$ & $\begin{array}{l}\text { Job-cutting, unfair pay, } \\
\text { various } \\
\text { discriminations }\end{array}$ \\
\hline Customers & External & $\begin{array}{l}\text { Right to be safe, right } \\
\text { to choose, right to be } \\
\text { informed, and right to } \\
\text { be heard }\end{array}$ & $\begin{array}{l}\text { Loss of product } \\
\text { security, and other } \\
\text { consumer rights }\end{array}$ \\
\hline Suppliers & External & $\begin{array}{l}\text { In-time pay for } \\
\text { product or service } \\
\text { delivery according to } \\
\text { contract }\end{array}$ & $\begin{array}{l}\text { Delayed pay for } \\
\text { delivery, no pay for } \\
\text { delivery }\end{array}$ \\
\hline Creditors & External & $\begin{array}{l}\text { In-time repay of } \\
\text { principals and } \\
\text { interests }\end{array}$ & $\begin{array}{l}\text { Delayed repay or no- } \\
\text { repay of principals } \\
\text { and interests }\end{array}$ \\
\hline Government & External & $\begin{array}{l}\text { Compliance with laws } \\
\text { and regulations in the } \\
\text { market, taxation }\end{array}$ & $\begin{array}{l}\text { Breaking laws and } \\
\text { regulations, unfair } \\
\text { competition, loss of } \\
\text { tax }\end{array}$ \\
\hline Community & External & $\begin{array}{l}\text { Job creation, } \\
\text { environmental } \\
\text { protection, } \\
\text { community } \\
\text { development }\end{array}$ & $\begin{array}{l}\text { Loss of job } \\
\text { opportunity, } \\
\text { Pollution of the } \\
\text { environment }\end{array}$ \\
\hline
\end{tabular}

It is important to notice that an unethical action of a firm may negatively impact the interests of a stakeholder directly or even several stakeholders indirectly at the same time. Alternatively, the stakeholder impacted by the firm's unethical behavior may also in turn negatively impact the development of the firm. For example, if the firm hurts its customers by selling unreliable or even dangerous products to them, they will in turn refuse to buy its products any more, which may put the business out of business. Thus, as a commercial business, it is essential to balance the interests of all stakeholders in its business operations.

\section{Review of strategic CSR}

Lantos (2000) in his paper The Boundaries of Strategic Corporate Social Responsibility defines the concept of strategic corporate social responsibility as strategic philanthropic cause which means that a firm considers the taking of social responsibility or charitable cause to be a kind of marketing campaign to realize its strategic objective of enlarging sales and profits as it believes that doing good to the society equals to promoting a firm's reputation and increasing its return. Vaughn (1999) also argues that strategic CSR is good for the long term benefit of a firm, since doing good will generate returns in the long run. Hatman (2002), and Ebert \& Griffin (2006) in their publications make discussions on the types of CSR covering ethical CSR, altruistic CSR and strategic, among which ethical CSR means supporting social causes based on clearly defined values and corporate consciousness norms, and altruistic CSR means 
contributing to the society without the purpose of getting returns. Furthermore, simply speaking, strategic CSR refers to a firm's good deed with the expectation or purpose of getting returns. It is commendable that strategic CSR should taken by firms because it balances the interests of both owners and the society. See Figure 2.2:

Figure 2.2: Comparison between altruistic CSR and strategic CSR

\begin{tabular}{|l|l|l|l|}
\hline Type of CSR & Definition & Advantage & Disadvantage \\
\hline Altruistic & $\begin{array}{l}\text { Taking social } \\
\text { responsibility for no } \\
\text { future returns }\end{array}$ & $\begin{array}{l}\text { High ethical } \\
\text { standard and } \\
\text { great deed }\end{array}$ & $\begin{array}{l}\text { Neglecting the } \\
\text { interests of } \\
\text { owners }\end{array}$ \\
\hline Strategic & $\begin{array}{l}\text { Taking social } \\
\text { responsibility for } \\
\text { future returns }\end{array}$ & $\begin{array}{l}\text { Balancing the } \\
\text { interests of both } \\
\text { owners and the } \\
\text { society }\end{array}$ & $\begin{array}{l}\text { Tools of marketing } \\
\text { or even cheating }\end{array}$ \\
\hline
\end{tabular}

In China, there have been some research findings on the issue of strategic CSR. Based on the reveiw, the paper finds that: Zhu (2006) makes an analysis of the strategic adjustment of business public relations under CSR, and argues that firms should develop the marketing strategy of strategic public relations to increase brand image and sales. (2009) made a study on the relationship between strategic CSR and corporate competitive advantages, confirming that strategic CSR initiatives provide some degree of support to the enhancement of a firm's competitiveness. Xia (2010) Mai also makes an empirical research on the impact of strategic CSR on the brand capital in China and argues that there is a positive relationship between the performance of strategic CSR and the increase of corporate brand. Li (2011) makes a related research and argues that there are three values of strategic CSR added to the increase of China's CSR management level. Xuan and Feng (2011) makes a detailed review of the basis, features, paths of strategic CSR. Luo (2011) develops a conceptual model for the recognition of strategic CSR initiatives. Zhang (2014) makes a review of research progress in strategic CSR in China.

\section{Researches on food firms' CSR issues}

From the review of literature, it can be seen that there are some Chinese researchers who have done some studies on food firms' CSR, such as Wang (2009) who makes a research on the relationship between food security and modern CSR, Zuo (2010) who makes analysis of Chinese food security management based on the perspective of ISO26000, Feng and Wu (2011) who explore into the problem of food firms' CSR triggered by food safety scandals, and so on. However, there is no research finding found out on the issue of food firms' CSR based on the view of strategic CSR. Therefore, it is of realistic importance to do the related in that it will enrich the scope of related study filed, and what is important is that it will help to better understand the food safety issue and ethical problem of food firms in China and put forward some suggestions for improvement.

The paper will try to answer the following questions: Are Chinese food firms regarding strategic CSR initiatives as tools of marketing or even cheating customers? What causes the ethical problems of Chinese food firms? What can be done to reduce and even prevent these problems?

\section{ANALYSIS OF ETHICAL PROBLEMS OF CHINESE FOOD FIRMS BASED ON STRATEGIC CSR Status of ethical problems of Chinese food firms}

Ever since 2008, the report of Sanlu Tainted Milk scandal has triggered the attention of the media and government as well as the general public to the ethical problems of Chinese food 
firms. The subsequently reported milk firms with a high profile cover nearly all the Chinese domestic and even foreign brand food firms such as Mengniu, Yili, Guangming, Nestle, KFC, McDonalds, and so forth. What is strange is that these firms are promoting themselves with the marketing strategy of actively participating in CSR initiatives, caring about the food safety and contributing to the society, such as their slogans of donating a cup of milk for the poor child a day, and advocating the management philosophy of "drink a cup of milk a day and strengthen the health of Chinese people". But in fact, they are not doing good deed when driven by the big money behind. They are maximizing their profits on the excuse of taking fiduciary responsibilities to their owners on the basis of sacrificing the interests of their customers. Simply speaking, these firms actually consider strategic CSR initiatives as tools of promoting their products and brands or even cheating their customers.

As a result of the media's transparency and customers' increasing awareness, more and more business ethical scandals are made public and punished in these years. These ethical problems can be summarized as three features, first, the scope of food safety problem is quickly widening to cover from milk, eggs, fish, and beans to nearly all the other types of food like fruit, wine, food oil, medicine, etc. Second, the method of immoral and illegal production and sales of food becomes more and more hidden and various. The food firms are using all kinds of chances and methods to cheat customers. Third, the degree of loss caused by the food safety problem is becoming more and more serious. The general public may feel unconfident for whatever they are eating. They are in doubt about anything they put into their mouth. The status of the people's concern reflects the bad consequence caused by the business scandals of food firms in the recent years, which can be seen in Figure 3.1:

Figure 3.1 Examples of ethical problems of Chinese food firms reported by the mass media in recent years

\begin{tabular}{|l|l|l|l|}
\hline $\begin{array}{l}\text { Type of unsecure } \\
\text { food }\end{array}$ & $\begin{array}{l}\text { Food firms } \\
\text { involved }\end{array}$ & $\begin{array}{l}\text { Potential harms to } \\
\text { health }\end{array}$ & $\begin{array}{l}\text { Year of } \\
\text { report }\end{array}$ \\
\hline Tainted milk & $\begin{array}{l}\text { Sanlu, and other } \\
\text { milk firms }\end{array}$ & $\begin{array}{l}\text { Causing the renal and } \\
\text { urogenital disorder or } \\
\text { even death of drinkers }\end{array}$ & 2008 \\
\hline $\begin{array}{l}\text { Nitrofuran hairy } \\
\text { crabs }\end{array}$ & Crab sellers & $\begin{array}{l}\text { Leading the cancer of } \\
\text { eaters }\end{array}$ & 2009 \\
\hline $\begin{array}{l}\text { Pork with lean } \\
\text { meat powder }\end{array}$ & $\begin{array}{l}\text { Pig husbandry } \\
\text { firms }\end{array}$ & $\begin{array}{l}\text { Leading the heart } \\
\text { disorder or death of } \\
\text { eaters }\end{array}$ & 2010 \\
\hline Drainage oil & $\begin{array}{l}\text { Food oil } \\
\text { producers and } \\
\text { sellers }\end{array}$ & $\begin{array}{l}\text { Causing harm to the } \\
\text { stomach of eaters and } \\
\text { even death }\end{array}$ & 2010 \\
\hline $\begin{array}{l}\text { Forged green } \\
\text { pork }\end{array}$ & $\begin{array}{l}\text { Walmart Chengdu } \\
\text { Store }\end{array}$ & $\begin{array}{l}\text { Pricing cheating to the } \\
\text { customer }\end{array}$ & 2012 \\
\hline $\begin{array}{l}\text { Glazed fruit } \\
\text { adding bleach } \\
\text { preservatives }\end{array}$ & $\begin{array}{l}\text { Glazed fruit } \\
\text { producers and } \\
\text { sellers }\end{array}$ & $\begin{array}{l}\text { Leading to the cancer of } \\
\text { eaters }\end{array}$ & 2012 \\
\hline Over-due meet & $\begin{array}{l}\text { McDonalds and } \\
\text { KFC }\end{array}$ & $\begin{array}{l}\text { Leading to the health } \\
\text { problems of eaters }\end{array}$ & 2015 \\
\hline
\end{tabular}

Source: Adapted from reports of the mass media 
In a summary, the current status quo of ethical problems of Chinese food firms is worrying and serious. It is commonly recognized that Chinese food firms in the current stage of development tend to regard strategic CSR initiatives as tools of marketing or even cheating customers from the fact or evidence that what they are saying is one thing while what they are doing is another. In the following is the analysis of the underlying reasons for the ethical problems.

\section{Underlying reasons for ethical problems of Chinese food firms}

The first reason is the natural consequence of people's living condition improvement. The concentrated breaking-out of the food safety problem in the recent years originates from the historical change of the Chinese food consumers. Dating back to the period before the openingup policy of earlier 1980s, there was a shortage of food in the whole country so how to fill our stomach was the most important issue to be concerned, and no one concerned about the ethical problem of food firms. But from 1984 to 2000, the country's food safety concern began to be in infantry. The government issued the Law of Food and Medicine Safety to enhance the supervision on organic food or green food. Ever since 2001, with the improvement of people's living condition, there have been more and more concerns about food safety, especially since the 2008 business scandal of Sanlu Tainted Milk, the ethical problem of Chinese food firms has been the systematic problem of large food firms in the industry rather that of smaller family food businesses.

In the current stage of Chinese economic development, a majority of Chinese food firms are regarding profit-making as its primary objectives, thus still tending to lose their bottom line in face of opportunities of making big money or regarding their CSR initiatives as tools of making more profits strategically. And at the same time, people or consumers in recent years begin to consider the quality of food as more and more important because of the improvement of people's living condition. Therefore, naturally, there concentrated breaking-out of food firms' business scandals becomes possible as a result of the people's increasing awareness of food safety and better eating for healthy life.

The second reason is the imperfect external institutional environment of the country. On the one hand, the related law and regulation on food safety need to be perfected to cover all types of food and all sections of the whole food supply chain. On the other hand, the whole-process supervision and investigation on food safety and food firms from the farm plantation to the dinner table has not be established to ensure that there is no ethical problem of food production and processing along the whole supply chain or value chain. For example, in the case of Sanlu Tainted Milk, the lack of whole-process regulation and investigation leads to the loss of the food firm's bottom line in operation. These issues include the leaping hole of governmental whole-process supervision mechanism for food firms, the lack of proactive supervision of the government authorities, the special care or loosened control given by the local government to the food firm in the local region. Therefore, the shortcoming of the external institutional condition is likely to result in the possibility or chance that food firms seek to maximize their profits by sacrificing the interests of stakeholders like customers or the general public with the advocating of strategic CSR initiatives such as donations to charity or green marketing activities.

The third reason is the imperfect internal management philosophy and practice of food firms. The reported immoral food firms have a common shortcoming in their internal management practice that is they have not established a correct management philosophy and a sound CSR management and supervision system within the organization to direct and control the behaviors of all functional departments along the whole value chain. For example, they have not established a well-defined code of ethics or shared core values for the whole organization 
to let all employees and managers know what is right and what is wrong, or what can be done and what can not be done. They have not put CSR strategic objectives into the overall organization's strategic plans so that there are clearly-stated evaluation standards of CSR performance each year, and in the corporate governance system, they have established a directly responsible CSR department with a director to be in charge of social audit and CSR performance in the whole organization. In addition, there are not $100 \%$ independent outside directors in the board to represent the interests of different stakeholders, because the directors or members are actually filled with their relatives and acquaintances in the board and control committees.

As a result of these above-mentioned shortcomings existing in the internal institutional system of these food firms, when facing the pressure of intensified market competition and highly-set profit-making target, managers of these food firms choose to ignore the quality of raw materials and finished in the upper value chain to seek for the reduction of operation costs and the maximization of profits. Immoral or illegal behaviors become fatal in the end because there is no person in charge. What is important is that the whole organization have a wrong management value that they consider CSR contributions as purely a marketing tool or tactics to retain existing customers or attract potential customers strategically. They say that they are pursuing the value of high quality, green production and social contribution, but in fact, what they are saying is one thing, but what they are doing is another, simply they are cheating the customers and causing damages to the public health with an outer clothing of making special contribution to the society.

\section{CONCLUSION AND SUGGESTION}

In conclusion, strategic CSR refers to the good deed of firms that is regarded as a means of marketing to improve their profits in the long term. Simply, the practice of CSR initiatives is designed to seek the increase of reputation and profit return. Based on the theoretical review and the case analysis of Chinese food firms' strategic CSR practices, the paper finds that Chinese food firms tend to regard strategic CSR initiatives as tools of marketing or even cheating customers. The underlying reasons for the ethical problems of food firms include the increase of consumers' awareness of the food quality and safety as a result of economic development and living condition improvement in recent years, the imperfect external institutional system of the country such as the related law and regulation as well as the control flaw in the whole-process of food production along the value chain, and the imperfect internal management philosophy and practice of food firms in China. It is thus suggested to take the following countermeasures from the joint force of both external and internal institutional systems so as to improve or even prevent the ethical problems of food firms:

First, in the construction of external institution, the legal authority should amend and perfect the related law and regulation on food safety, for example, the adding of provisions on more serious punishment on food-safety-related crimes and unethical acts by increasing the costs of illegal and immoral behaviors. The government agency should strengthen the control of market entry and whole-process supervision on food firms along the whole value. And at the same time, it is necessary to enhance the media's transparency and social organizations' norming roles in the regulation on food firms' conducts.

Second, in the construction of internal institution, food firms should be required to develop the code of conducts and enlist the objective of CSR strategies into their strategic plans for implementation to let managers and workers have the awareness of ethics and the target of 
CSR performance. Food firms are suggested to establish an effective corporate governance system to balance the interests of different stakeholders.

Third, food firms are suggested to appoint a director in charge of social audit and CSR strategy implementation. But of course, leaders of the firms should support the CSR efforts with the fostering or cultivating of a CSR culture awareness and correct management values, so that all staff are clear about the values, rules and norms.

Third, food firms are suggested to enhance the training and education for employees to be able to make proper ethical decisions and reasoning when faced the ethical issue in their daily work environment and business management practices.

\section{ACKNOWLEDGMENT}

This paper is sponsored by the 2016 Project of Higher Education Teaching Quality and Reform (No.Yuejiaogaohan [2016]236) sponsored by Guangdong Provincial Department of Education.

\section{References}

Boone, L.E., and Kurtz D. Contemporary Business (Tenth Edition) [M]. Harcourt College Publishers, 6277 Harbor Drive,, Orlando, FL32887-6777, 2002

Friedman, M. The Methodology of Positive Economics, Essays on Positive Economics [M]. University of Chicago Press, 1953

Friedman, M. The Social Responsibility of Business Is to Increase Its Profits. The New York Times Magazine, September 13th, 1973:173-178.

Carroll, A.B. The Pyramid of Corporate Social Responsibility: Toward the Moral Management of Organizational Stakeholders[J]. Business Horizons, 1991. Available from:

http://w3.uniroma1.it/moscarini/materiale\%20seminario/Carroll.pdf

Carroll, A.B. Corporate Social Responsibility: Evolution of a Definitional Construct[J]. Sage Journals Online, 1999. Available from: http://bas.sagepub.com/content/38/3/268

Vaughn, S. Firms Find Long-term Rewards in Doing Good. Business Ethics [J]. Dushkin/McGraw-hill, Guilford, CT, 1999, pp.199

Freeman, R.E. Strategic Management: A Stakeholder Approach[M]. 3rd. New York: Cambridge University Press, 2010

Lantos, D.P. The Boundaries of Strategic Corporate Social Responsibilities[J]. Journal of Consumer Marketing, Volume 18 No.7 2001, pp.595-632

Hartman,L. P. Perspectives in Business Ethics (2nd edition) [M]. McGraw-Hill Higher Education, a division of McGraw-Hill Companies, 2002, pp.260-264

Ebert, R.J., and Griffin, R.W. Business Essentials [M]. 5th ed. Beijing: China Remin University Press, 2006

Zhu,W.M. Strategic adjustment of business public relations under the condition of CSR[J]. Journal of Shanghai Business School, 2006 (4)

Mai, Y. Research on the relationship between strategic CSR and firms' competitiveness[J]. Special Economic Zone, 2009 (4)

Xia,X.C. An empirical study on the effect of strategic CSR on the asset of brand[J]. Journal of Tianjin University, $2010(2)$

Li,W. Three values added by strategic charity to the increase of CSR management level in China[J]. WTO Economic Guide, 2011 (7)

Xuan, Y.F. and Feng, L.H. The Implementation foundation, feature and path of strategic CSR [J]. Journal of China Securities and Futures, 2011(8)

Luo, W. The construction of a conceptual model for the recognization of strategic CSR iniatives[J]. Business Times, $2011(1)$ 
Zhang, S.L. The research progress of researches on strategic CSR in China[J]. Business Times, 2014 (1)

Wang, Z.L. Food Security and Modern CSR. Shanghai Economic Research[J]. Shanghai Economic Study, 2009 (1)

Zuo, W., et al. Analysis of Food Security Management from the Perspective of ISO26000[J]. Journal of Corporate Social Responsibility, 2010 (4)

Feng Z.L. and Wu, M. Research on the problem of food firms' CSR triggered by food safety scandals[J]. China General Accountants, 2011 (8) 